Rediscovering America 
TWENTIETH-CENTURY JAPAN :

THE EMERGENCE OF A WORLD POWER

Irwin Scheiner, Editor

I. Labor and Imperial Democracy in Prewar Japan, by Andrew Gordon

2. Complicit Fictions: The Subject in the Modern Japanese Prose Narrative, by James A. Fujii

3. The Making of a Japanese Periphery, I750-I920, by Kären Wigen

4. The Abacus and the Sword: The Japanese Penetration of Korea, I895-I9Io, by Peter Duus

5. Authenticating Culture in Imperial Japan: Kuki Shuzo and the Rise of National Aesthetics, by Leslie Pincus

6. Splendid Monarchy: Power and Pageantry in Modern Japan, by T. Fujitani

7. Marketing the Menacing Fetus in Japan, by Helen Hardacre

8. Japan's Total Empire: Manchuria and the Culture of Wartime Imperialism, by Louise Young

9. Mirror of Modernity: Invented Traditions of Modern Japan, edited by Stephen Vlastos

Io. Hiroshima Traces: Time, Space, and the Dialectics of Memory, by Lisa Yoneyama

I I. MAVO: Japanese Artists and the Avant-Garde, I905-I93 I, by Gennifer Weisenfeld

I2. Reconfiguring Modernity: Concepts of Nature in Japanese Political Ideology, by Julia Adeney Thomas

I3. The City as Subject: Seki Hajime and the Reinvention of Modern Osaka, by Jeffrey E. Hanes

I4. Perfectly Japanese: Making Families in an Era of Upheaval, by Merry Isaacs White

I 5. The Social Sciences in Modern Japan: The Marxian and Modernist Traditions, by Andrew E. Barshay

16. Reasonable Men, Powerful Words: Political Culture and Expertise in TwentiethCentury Japan, by Laura Hein

17. Lever of Empire: The International Gold Standard and the Crisis of Liberalism in Prewar Japan, by Mark Metzler

I8. Ordinary Economies in Japan: A Historical Perspective, I750-I950, by Tetsuo Najita

19. Rediscovering America: Japanese Perspectives on the American Century, edited by Peter Duus and Kenji Hasegawa 


\section{Rediscovering America}

Japanese Perspectives

on the American Century

EDITED BY

Peter Duus and Kenji Hasegawa

무

UNIVERSITY OF CALIFORNIA PRESS

Berkeley • Los Angeles • London 
University of California Press, one of the most distinguished university presses in the United States, enriches lives around the world by advancing scholarship in the humanities, social sciences, and natural sciences. Its activities are supported by the UC Press Foundation and by philanthropic contributions from individuals and institutions. For more information, visit www.ucpress.edu.

University of California Press

Berkeley and Los Angeles, California

University of California Press, Ltd.

London, England

(C) 20 II by The Regents of the University of California

Library of Congress Cataloging-in-Publication Data

Rediscovering America : Japanese perspectives on the American century / edited by Peter Duus and Kenji Hasegawa.

p. cm. - (Twentieth-century Japan ; I9)

Includes bibliographical references.

ISBN 978-0-520-26843-2 (cloth : alk. paper)

ISBN 978-0-520-26845-6 (pbk. : alk. paper)

I. United States-Foreign public opinion, Japanese.

2. United States-Civilization-2oth century-Foreign public opinion, Japanese. 3. Public opinion-Japan.

4. United States-Relations-Japan. 5. Japan-

Relations-United States. I. Duus, Peter.

II. Hasegawa, Kenji.

EI83.8.J3R37 20 II

$327.7305209^{\prime} 04-\mathrm{dc} 22$

2011004433

Manufactured in the United States of America

\begin{tabular}{|c|c|c|c|c|c|c|c|c|c|}
\hline 20 & I9 & I & & I7 & I6 & I 5 & I4 & I3 & I 2 \\
\hline 0 & 9 & 8 & 7 & 6 & 5 & 4 & 2 & I & \\
\hline
\end{tabular}

In keeping with a commitment to support environmentally responsible and sustainable printing practices, UC Press has printed this book on Rolland Enviroı oo, a I00\% post-consumer fiber paper that is FSC certified, deinked, processed chlorine-free, and manufactured with renewable biogas energy. It is acid-free and EcoLogo certified. 